Original article

\title{
EFFECT OF DIETARY VERNONIA AMYGDALINA DEL. SUPPLEMENTATION ON SOME BIOLOGICAL PARAMETERS OF MILT OF MALE AFRICAN CATFISH (CLARIAS GARIEPINUS)
}

\author{
O. O. AJALA \& A. O. OWOYEMI
}

\begin{abstract}
Department of Veterinary Surgery and Reproduction, Faculty of Veterinary Medicine, University of Ibadan, Nigeria
\end{abstract}

\begin{abstract}
Summary
Ajala O. O. \& A. O. Owoyemi, 2016. Effect of dietary Vernonia amygdalina Del. supplementation on some biological parameters of milt of male African catfish (Clarias gariepinus). Bulg. J. Vet. Med., 19, No 1, 30-39.

The effect of Vernonia amygdalina Del. leaves on the reproductive potential of male Clarias gariepinus was investigated using 56 fish $(425 \pm 75.7 \mathrm{~g})$. Four diets with crude protein level of $45 \%$ were formulated with different inclusion levels of $V$. amygdalina leaves. The leaves were added to the basal diet at $0 \%$ (control), 5\%,10\% and 15\% inclusion levels. The 56 male C. gariepinus were randomly distributed in duplicate into 4 concrete ponds and 4 plastic tanks at a stocking density of 7 fish per concrete pond and plastic tank. The fish were fed at $3 \%$ body weight twice daily for 45 days. The milt was then analysed for some biological parameters. Motility and liveability percentage values $(88.33 \pm 14.720 \%$ and $91.83 \pm 6.824 \%$ respectively) were the lowest in the control ( $0 \%)$ group but the difference was not significant $(\mathrm{P}>0.05)$ across the groups. Morphology studies showed that total sperm abnormalities were the lowest in the $10 \%$ group $(45.67 \pm 2.73)$ and total normal sperm cell number was the highest in the $10 \%$ group $(393.83 \pm 14.15)$. Total sperm counted in morphology study was the highest in controls $(442.50 \pm 22.12)$. The differences in these values were not significant across the groups $(\mathrm{P}>0.05)$. The results of the study show that studied inclusion levels of $V$. amygdalina did not have significant effects on sperm motility, liveability and morphology; hence it can be concluded that Bitter leaf may be included at the studied levels with no untoward effect in the diet of male C. gariepinus.
\end{abstract}

Key words: Clarias gariepinus, milt, motility, percentage liveability, morphology, Vernonia amygdalina Del.

\section{INTRODUCTION}

African catfish, Clarias gariepinus is one of the highly priced food fish in Nigeria and most parts of the world. An omnivorous scavenger that eats everything it

finds, the African catfish is particularly amenable to the farming practices of smallholders, who comprise the majority of farmers in developing countries (Musa 
et al., 2012). The availability of gametes throughout the year is important to ensure a constant supply of fish (Oteme et al., 1996). This availability is dependent on gonadal development and fecundity, which are subsequently affected by dietary nutrients (Izquierdo et al., 2001). The quality of sperm is highly variable and dependent on feeding regime, feed quality and the rearing temperature of the fish (Adewumi et al., 2005). Other factors include stress, age of broodstocks, breeding season, diseases, hormonal induction and spermiation (Azlina et al., 2011). Androgen synthesis and sperm quality are positively impacted by dietary lipid and fatty acids (NyinaWamwiza et al., 2012). In the rainbow trout, ascorbic acid deficiency reduced both sperm concentration and motility, and thus fertility (Ciereszko \& Dabrowski, 1995). Insufficient intake of energy and protein has been associated with suboptimal reproductive performance (Bindari et al., 2013). Sperm quality is determined by sperm motility and fertilisation potential (Adewumi et al., 2005).

The use of plants as fertility enhancers is now receiving attention in aquaculture (Dada et al., 2010). V. amygdalina Del., commonly called Bitter leaf, is a perennial shrub belonging to the family Asteraceae (Ijeh \& Ejike, 2011). Indigenous edible vegetable leaves such as Bitter leaf are inexpensive sources of proteins, carbohydrates, minerals, vitamins and fibres. It is rich in beta-carotene, a precursor of vitamin A (Aregheore, 2012) and ascorbic acid (Ucheck, 2004). Phytochemicals present in the plant include anthraquinones, tannins, flavonoids, alkaloids, saponins, glycosides and terpenoids (Audu et al., 2012). The vitamins $A$ and $C$, and the phytochemicals are responsible for its anti-oxidant properties (Hamzah et al., 2013). The A-series saponins have been shown to be responsible for the bitter taste of $V$. amygdalina (Ijeh \& Ejike, 2011). Apart from its dietary value, the leaf is also believed by many Africans to possess therapeutic properties on almost every system of the body. The leaf is antiparasitic (Ucheck, 2004), hypoglycaemic and hypolipidaemic (Arhoghro et al., 2009), hepatoprotective (Farombi \& Owoeye, 2011), nephroprotective (Ebong, 2011), antidiarrhoeic (Hassan et al., 2007), anti-cancer (Hamzah et al., 2013), antifebrile (Areghore, 2012) and aids healing (Ucheck, 2004). In humans the effects of the plant on the reproductive system have been observed mainly in women but reports have been mostly conflicting. For example, in South Africa and Ethopia, it is used traditionally for its anti-fertility effect. (Ayele, 2006) while in orthodox medicine, the plant has been used as fertility inducer in infertile women (Areghore, 2012). Also, in Ivory Coast, the leaves are used to maintain pregnant women till childbirth (Nalule et al., 2013) while its use in South Eastern Nigeria to encourage milk let-down implies that the extracts may be capable of hastening parturition or causing abortion if used in preterm pregnancy (Ijeh et al., 2011). In animals, reports by researchers also vary widely. Oyeyemi et al. (2008) revealed that uncontrolled use of Vernonia amygdalina has an adverse effect on the spermiogram and spermatozoa morphology of the intact male Wistar rats. In same vein, the methanolic extract of the plant caused significant decrease in testosterone levels and sperm motility of treated rats, thus having a deleterious effect on the reproductive functions in male albino rats (Oyedeji et al., 2013). The opposite was the case in fish where the leaves of the plant were reported to be very useful as fertility enhancer in male Heterobranchus bidorsalis 
broodstock management (Francis et al., 2013). The use of a combination of the extracts of $V$. amygdalina and Ocimum gratissimum was found to combat adverse effects of diabetes on the testes of Wistar rats (Asuquo et al., 2010). In female mice the crude extract had anti-implantation and abortifacient effects making $V$. amygdalina a potentially anti-fertility agent (Ayele, 2006).

The demand for fish is continuously increasing and can only be confronted with correspondingly increasing fish yield. This increased demand is difficult for the average farmer to meet up with since to ensure continuous fish yield, there must be availability of gametes throughout the year (Oteme et al., 1996) which is consequently hinged on feeding fish with essential nutrients (Izquierdo et al., 2001). The cost of procuring conventional fish feed is high; it therefore becomes imperative to look into ways of improving fish production at affordable cost using locally available vegetables. Having an abundance of some of the nutrients essential for fish reproduction - carbohydrates, lipids, vitamins $\mathrm{A}$ and $\mathrm{C}, V$. amygdalina Del. has considerable potential for use as a nonconventional feed resource in fish feed formulation and production. This study therefore aims to evaluate the effects of Bitter leaf inclusion in fish diet on the semen quality of male Clarias gariepinus with the objective of determining the suitability of Bitter leaf for fish consumption.

\section{MATERIALS AND METHODS}

\section{Experimental design}

The research was carried out at a vacant fish farm in Felele, Ibadan, Oyo State between April and May, 2013. Ibadan is located in the Southwestern part of Nigeria, latitude and longitude $7.23 \mathrm{~N}, 3.52 \mathrm{E}$ respectively (Balogun, 2000). Fifty-six mature Clarias gariepinus males (weight $425 \pm 75.7 \mathrm{~g}$ ) were procured from a commercial fish farm in Ibadan. Vernonia amygdalina Del. (Bitter leaf) leaves were harvested from Orita-Challenge, Ibadan, Oyo State and were identified and authenticated at the Forest Research Institute of Nigeria, Ibadan, Oyo State with Authentication number FHI 109940. The leaves were soaked for $24 \mathrm{~h}$ in water and subsequently sundried till they were brittle. The dried leaves were later ground and added to the feed in graded proportions of $0 \mathrm{~g} / \mathrm{kg}$ diet (control diet), $50 \mathrm{~g} / \mathrm{kg}$ diet (5\% inclusion level), $100 \mathrm{~g} / \mathrm{kg}$ diet $(10 \%$ inclusion level) and $150 \mathrm{~g} / \mathrm{kg}$ diet (15\% inclusion level) (Arhoghro et al., 2009). The mixture was thoroughly homogenised and pelletised. Proximate and mineral analyses (Tables 1 and 2) were carried out on the leaves before and after processing to assess the nutrients and anti-nutritional factor, saponin lost to processing. Analyses were done using Association of Official Analytical Chemist, A.O.A.C., (2005) methods.

The fish were grouped into concrete ponds randomly at 7 fish per pond ( $1 \mathrm{~m} \times$ $1 \mathrm{~m} \times 1 \mathrm{~m})$ with each treatment group having a duplicate in plastic containers $(1 \mathrm{~m} \times 1 \mathrm{~m} \times 1.5 \mathrm{~m})$. The experiment was conducted in a semi-intensive monoculture system with water renewal once a week. The four diets: $0 \%, 5 \%, 10 \%$ and $15 \%$ were randomly assigned to the fish. The fish were fed commercial feed containing $45 \%$ crude protein and varying inclusion levels of processed Bitter leaf for 45 days.

The experiment was conducted under conditions of $12 \mathrm{~h}$ photoperiod and $12 \mathrm{~h}$ darkness. Rain water was used. The following water quality parameters were obtained using the methods described by 
Table 1. Proximate analysis of $V$. amygdalina leaves

\begin{tabular}{lcc}
\hline Content & Pre-soaked leaves & Post-soaked leaves \\
\hline Total carbohydrates $(\%)$ & 37.92 & 33.60 \\
Lipids $(\%)$ & 4.31 & 2.59 \\
Saponins $(\%)$ & 0.50 & 0.28 \\
Vitamin A $(\mu \mathrm{g} / 100 \mathrm{~g})$ & 3728.50 & 3241.40 \\
Vitamin C $(\mathrm{mg} / 100 \mathrm{~g})$ & 18.30 & 13.81 \\
\hline
\end{tabular}

Table 2. Mineral analysis of $V$. amygdalina leaves

\begin{tabular}{lcc}
\hline Content & Pre-soaked leaves & Post-soaked leaves \\
\hline Calcium (\%) & 2.26 & 1.86 \\
Magnesium (\%) & 0.19 & 0.32 \\
Potassium (\%) & 0.22 & 1.21 \\
Sodium (\%) & 0.01 & 0.02 \\
Manganese (\%) & 0.004 & 0.004 \\
Iron (\%) & 0.06 & 0.05 \\
Copper (\%) & 0.001 & 0.001 \\
Zinc (\%) & 0.007 & 0.003 \\
Nitrogen (\%) & 2.93 & 3.18 \\
\hline
\end{tabular}

American Public Health Association, APHA (1998); dissolved oxygen $8.7 \mathrm{mg} / \mathrm{L}$, nitrate and ammonia levels - $2.12 \mathrm{mg} / \mathrm{L}$ and $0.43 \mathrm{mg} / \mathrm{L}$ respectively, $\mathrm{pH}$ 7.38. Temperature range was $25{ }^{\circ} \mathrm{C}-30{ }^{\circ} \mathrm{C}$.

The fish were allowed to acclimatise for 2 weeks before being introduced into the concrete ponds and plastic containers. The fish were fed pelletised feed at 3\% body weight twice daily. After the experimental feeding period of 45 days, the fish were taken to the laboratory for laboratory procedures.

\section{Milt collection and analysis}

Fish were sacrificed by stunning (Adakole, 2012). The ventral surface of the body was incised to remove the testes. Milt was collected from the testes by dissecting the testes with a razor blade and squeezing out. Sperm activation was done at room temperature (Verma et al., 2009). The milt was evaluated for mass activity, motility, percentage liveability and morphology.

Macroscopic examination of the semen was done to observe mass activity (swirl motion) of the spermatozoa by putting a drop of milt on a warm slide and viewing at $\times 4$ objective lens of the light microscope.

Motility was evaluated by subjectively assessing movement of sperm cells under the microscope (Viveiros et al., 2001; Fauvel et al., 2010). A drop of semen was put on a warm slide plus warm distilled water. A cover slip was put on the slide and the slide was viewed under the light microscope at a magnification of $\times 40 \mathrm{ob}$ jective lens. Only sperm cells moving in a head forward unidirectional motion were included in the motility count while sperm cells moving in circles, in backward direction or showing pendulating movements were excluded.

Percentage liveability was evaluated by putting one drop of semen on a warm 
Effect of dietary Vernonia amygdalina Del. supplementation on some biological parameters of milt ...

slide. A drop of Eosin-Nigrosin stain was added and the slide was viewed under the light microscope at $\times 40$ objective lens. The live/dead ratio was observed and based upon the principle of eosin penetrating and staining the dead sperm cells whereas viable sperm cells repel the stain (Zemjanis, 1970). Percentage liveabililty was evaluated by direct counting of sperm cells (Fauvel et al., 2010). Hundred sperm cells were counted from different fields of the slide out of which sperm cells that did not pick the stain (the live ones) were counted and expressed as a percentage.

Morphology was used to determine the presence and incidence of morphologically defective spermatozoa through the use of Wells \& Awa stain smear. A drop of semen was placed on a warm slide and with another slide; a smear was made and stained with Wells \& Awa stain. The stained smear was air-dried and observed under the light microscope at $\times 40$ objective lens. The spermatozoa abnormalities were classified into head, midpiece and tail abnormalities (Sekoni et al., 1981) and expressed as percentages derived by dividing the mean value for a given parameter in a particular group by the mean value of the total sperm counted for that group multiplied by 100 .

\section{Statistical analysis}

Data was subjected to one-way analysis of variance to compare variation across the treatment groups. Any test value with $\mathrm{P}$ value less than 0.05 was considered significant (Orlu \& Ogbalu, 2011). The data were presented as mean and standard deviation.

\section{RESULTS}

Macroscopic examination revealed rapid $(++++)$ swirl motion in all the groups. There was no significant difference $(\mathrm{P}>0.05)$ among the treatment groups in the mean motility and percentage liveability values of spermatozoa (Table 3 ). The sperm motility in $0 \%$ (control), 5\%,10\% and $15 \%$ groups was $83.33 \%, 87.17 \%$, $89.17 \%$ and $86.25 \%$ respectively. The $10 \%$ group had the highest value of all. Mean liveability percentages in the four groups were $91.83 \%(0 \%), 93.50 \%$ (5\%), $96.50 \%(10 \%)$ and $94.50 \%(15 \%)$. The highest value was observed in the $10 \%$ group just as seen in motility.

Table 4 shows the effects of treatment levels on the morphology of spermatozoa in the testes. There was no significant difference among the treatment groups $(\mathrm{P}>0.05)$ in the tailless head percentages of group $0 \%(1.36 \%)$, group $5 \%(1.40 \%)$, group $10 \%(1.18 \%)$ and group $15 \%$ $(1.20 \%)$. The $10 \%$ group had the least value. Mean values for abaxial mid-piece were $2.00 \%(0 \%), 1.95 \%(5 \%), 1.75 \%$ $(10 \%)$ and $1.83 \%(15 \%)$. The $10 \%$ group had the least value but without significant difference among the treatment groups $(\mathrm{P}>0.05)$. No significant difference was

Table 3. Effects of dietary $V$. amygdalina levels on motility and percent liveability of spermatozoa in the testes of African catfish

\begin{tabular}{llc}
\hline Treatments & Motility (\%) & Percent liveability (\%) \\
\hline $0 \%$ & $83.33 \pm 14.720$ & $91.83 \pm 6.824$ \\
$5 \%$ & $87.17 \pm 8.727$ & $93.50 \pm 6.775$ \\
$10 \%$ & $89.17 \pm 7.360$ & $96.50 \pm 1.643$ \\
$15 \%$ & $86.25 \pm 11.087$ & $94.50 \pm 3.317$ \\
\hline
\end{tabular}


Table 4. Effects of dietary $V$. amygdalina levels on morphological parameters of spermatozoa in the testes of African catfish

\begin{tabular}{lcccc}
\hline \multirow{2}{*}{ Abnormality } & \multicolumn{4}{c}{ Treatments } \\
\cline { 2 - 5 } & $0 \%$ & $5 \%$ & $10 \%$ & $15 \%$ \\
\hline Heads & & & \\
Tail-less heads & $6.00 \pm 10$ & $6.00 \pm 0.89$ & $5.17 \pm 0.75$ & $5.25 \pm 0.50$ \\
& $(1.36 \%)$ & $(1.40 \%)$ & $(1.18 \%)$ & $(1.20 \%)$ \\
\hline Middle piece & & & \\
Abaxial (\%) & $8.83 \pm 0.75$ & $8.33 \pm 1.03$ & $7.67 \pm 1.21$ & $8.00 \pm 1.83$ \\
& $(2.00 \%)$ & $(1.95 \%)$ & $(1.75 \%)$ & $(1.83 \%)$ \\
Coiled (\%) & $9.00 \pm 0.89$ & $8.67 \pm 0.82$ & $8.67 \pm 0.52$ & $8.50 \pm 1.00$ \\
& $(2.03 \%)$ & $(1.96 \%)$ & $(1.97 \%)$ & $(1.94 \%)$ \\
\hline Tails & & & \\
Simple bent (\%) & $8.33 \pm 0.82$ & $9.50 \pm 1.05$ & $8.00 \pm 0.89$ & $8.75 \pm 0.50$ \\
Coiled (\%) & $(1.88 \%)$ & $(2.22 \%)$ & $(1.82 \%)$ & $(2.00 \%)$ \\
Coiled around the head, \% & $8.50 \pm 1.38$ & $8.83 \pm 0.98$ & $8.50 \pm 0.84$ & $8.25 \pm 0.96$ \\
& $(1.92 \%)$ & $(2.00 \%)$ & $(1.93 \%)$ & $(1.89 \%)$ \\
Headless tail (\%) & $1.33 \pm 0.52$ & $1.17 \pm 0.41$ & $1.33 \pm 0.52$ & $1.25 \pm 0.50$ \\
& $(0.30 \%)$ & $(0.27 \%)$ & $(0.30 \%)$ & $(0.29 \%)$ \\
Rudimentary (\%) & $5.00 \pm 0.63$ & $5.83 \pm 0.75$ & $4.33 \pm 1.03$ & $4.25 \pm 1.26$ \\
& $(1.13 \%)$ & $(1.36 \%)$ & $(0.99 \%)$ & $(0.97 \%)$ \\
\hline Total abnormalities (\%) & $2.00 \pm 0.89$ & $2.83 \pm 0.41$ & $2.00 \pm 0.89$ & $2.25 \pm 0.96$ \\
& $(0.45 \%)$ & $(0.66 \%)$ & $(0.46 \%)$ & $(0.52 \%)$ \\
Total normal (\%) & $49.00 \pm 3.79$ & $51.17 \pm 1.47$ & $45.67 \pm 2.73$ & $46.50 \pm 1.91$ \\
& $(11.07 \%)$ & $(11.96 \%)$ & $(10.39 \%)$ & $(10.64 \%)$ \\
Total sperm counted & $393.50 \pm 23.87$ & $376.50 \pm 11.69$ & $393.83 \pm 14.15$ & $390.75 \pm 10.21$ \\
\hline & $(88.93 \%)$ & $(88.04 \%)$ & $(89.61 \%)$ & $(89.37 \%)$ \\
& $442.50 \pm 22.12$ & $427.67 \pm 12.16$ & $439.50 \pm 16.20$ & $437.25 \pm 9.03$ \\
\hline
\end{tabular}

seen among the groups for coiled midpiece $-2.03 \%, 1.96 \%, 1.97 \%$ and $1.94 \%$ in groups supplemented with $0 \%, 5 \%$, $10 \%$ and $15 \% \mathrm{~V}$. amygdalina Del. leaves. The $15 \%$ group recorded the lowest value.

No significant difference in tail abnormalities $(\mathrm{P}>0.05)$ occurred across the groups. The 5\% group had the highest percentage of abnormalities among all the categories of tail abnormalities except for coiled around the head abnormality. Percentages for simple bent tail were $1.88 \%$ in control fish and $2.22 \%(5 \%), 1.82 \%$ $(10 \%)$ and $2.00 \%(15 \%)$. Respective values obtained for coiled tail were $1.92 \%$, $2.00 \%, 1.93 \%$ and $1.89 \%$. Coiled around the head tail prevalence was $0.03 \%(0 \%)$, $0.27 \%(5 \%), 0.30 \%(10 \%)$ and $0.29 \%$ $(15 \%)$, whereas respective headless tail percentages were $1.13 \%, 1.36 \%, 0.99 \%$ and $0.97 \%$. Percentages for rudimentary tail were $0.45 \%$ in the control group, $0.66 \%$ in the $5 \%$ group, $0.46 \%$ in $10 \%$ group and $0.52 \%$ in the $15 \%$ group.

Percentages of total sperm abnormalities, total normal spermatozoa and total number of sperm cells counted in morphology evaluation were not significantly different $(\mathrm{P}>0.05)$ across the groups although the $10 \%$ group had the least percentage of abnormal sperm cells and highest percentage of normal sperm cells. The 
control group had the highest total spermatozoa mean value $(442.50 \pm 22.12)$. Abnormal sperm prevalence was $11.07 \%$ (group 0\%), 11.96\% (group 5\%), 10.39\% (group $10 \%$ ) and $10.64 \%$ in the $15 \%$ group.

\section{DISCUSSION}

Sperm quality can be quantified by evaluation of sperm motility and fertilisation rate but the former is a faster approach than the latter (Fauvel et al., 2010). In this study, sperm motility values increased parallelly to dietary content of $V$. amygdalina. This shows that Bitter leaf supports sperm motility and agrees with the report of Francis et al., (2013) that motility increased with inclusion levels of $V$. amygdalina in the diet of the giant African catfish (Heterobranchus bidorsalis) broodstock. It also agrees with Dada \& Ogunduyile (2011) that motility was the lowest in the control group and increased proportionally to levels of Mucuna pruriens fed to African catfish broodstock. This is contrary to the report of Orlu \& Ogbalu, (2011) that the exposure of $C$. gariepinus to increasing extract concentrations of L. alopecuroides (Vahl) caused a decrease in sperm motility. The increased motility observed in treated groups may be due to the carbohydrate, lipid and vitamin $\mathrm{C}$ contents of the leaves. Vitamin C-deficient diet is known to decrease sperm motility (Ciereszko \& Dabrowski, 1995). In fish, glucose is the major substance utilised for energy used in motility (Ayoola, 2009). Carbohydrate content of $V$. amygdalina is a rich source of this energy much needed for motility.

Percentage liveability has a direct correlation with sperm motility since only live cells can be motile hence the higher the motility the higher the percent live- ability and vice-versa. That was the case in this study. The results obtained in this study showed higher percentage liveability values in the treated groups as was observed for sperm motility although the difference was not significant. This suggests that the leaves increase sperm viability opposite to the report of Oyeyemi et al. (2011) that male C. gariepinus treated with Aloe vera gel extract had decreased sperm viability. The higher liveability percentages obtained in groups fed Bitter leaf though not significant may be associated with the supplementary lipid, vitamin $\mathrm{A}$ and vitamin $\mathrm{C}$ derived from $V$. amygdalina in their diets.

Sperm defect is attributable to the activities of free radicals (Ligha et al., 2013). These radicals cause conditions like lipid peroxidation, protein oxidation, DNA damage and cellular degeneration. The activities of these free radicals can be checked by anti-oxidants such as present in the Bitter leaf (Hamzah et al., 2013). Yan et al. (2013) reported that increased dietary fatty acid intake also decreased sperm deformity rate in male Sprague Dawley rats. Increased dietary lipid and anti-oxidant in the feed of groups fed higher levels of $V$. amygdalina $(10 \%$ and $15 \%)$ might have contributed to lower though not significant sperm morphology abnormalities. These groups not surprisingly had also the highest values of spermatozoa with normal morphology.

High milt production is of vital importance in artificial reproduction of fish, as large amount of spermatozoa gets wasted due to external factors such as poor handling of milt and short motility time of spermatozoa (Verma et al., 2009). The high sperm count seen in the control group and the decreased sperm count in groups fed with $V$. amygdalina though not significantly different might be suggestive 
that the plant is not androgenic. Lower sperm counts observed in treated groups agrees with the report of Orlu \& Ogbalu (2011) that the exposure of $C$. gariepinus to extract concentrations of $L$. alopecuroides (Vahl) caused a decrease in sperm output. It also agrees with the report of Oyeyemi et al. (2011) that C. gariepinus groups treated with Aloe vera gel extract had decreased total sperm count than the control. The findings are contrary to the results of Adeparusi et al., (2010) that male C. gariepinus fed Kigelia Africana had significantly higher sperm count than the control.

In conclusion, the non-significant effects of the V.amygdalina leaves on semen parameters such as motility, liveability percentage and morphology makes the plant relatively safe at tested inclusion levels for use as a feed supplement in the diet of male $C$. gariepinus. However, further studies should be carried out to harness the potentials inherent in the Bitter leaf for reproduction by isolating the aforementioned essential nutrients needed for improved sperm quality from the leaves and conducting feeding trials.

\section{ACKNOWLEDGMENTS}

The authors would like to acknowledge the support of the staff of the Reproduction Laboratory, Department of Veterinary Surgery and Reproduction, University of Ibadan, Nigeria, as well as Engr. Odunfa and Adeniyi Aderibigbe for their assistance during the conduct of the study.

\section{REFERENCES}

Adakole, J. A., 2012. Changes in some haematological parameters of the African catfish (Clarias gariepinus) exposed to metal finishing company effluent. Indian Journal of Science and Technology, 5, 4.
Adeparusi, E. O., A. A. Dada \& O. V. Alale, 2010. Effects of medicinal plant (Kigelia africana) on sperm quality of African catfish Clarias gariepinus (Burchel, 1822) broodstock. Journal of Agricultural Science, $\mathbf{2}, 1$.

Adewumi, A. A., V. F. Olaleye \& E. A. Adesulu, 2005. Egg and sperm quality of the African catfish, Clarias gariepinus (Burchell) broodstock fed differently heated soybeanbased diets. Research Journal of Agriculture and Biological Sciences, 1, 17-22.

A.O.A.C., 1990. Official methods of analysis, Association of Official Analytical Chemists, $15^{\text {th }}$ edn, Arlington, Virginia.

APHA, 1998. Standard Methods for the Examination of Water and Wastewater. $20^{\text {th }}$ edn, American Public Health Association, New York, pp. 1268.

Aregheore, E. M., 2012. Nutritive value and inherent anti-nutritive factors in four indigenous edible leafy vegetables in human nutrition in Nigeria: A review. Journal of Food Resource Science, 1, 1-14.

Arhoghro, E. M., K. E. Ekpo, E. O. Anosike \& G. O. Ibeh, 2009. Effect of aqueous extract of Bitter leaf (Vernonia amygdalina Del) on carbon tetrachloride $\left(\mathrm{CCl}_{4}\right)$ induced liver damage in albino Wistar rats. European Journal of Scientific Research, 26, 115-123.

Asuquo, O. R., A. G. Edet, O. Mesembe \& J. Atanghwo, 2010. Ethanolic extracts of Vernonia amygdalina and Ocimum gratissimum enhance testicular improvement in diabetic Wistar rats. The Internet Journal of Alternative Medicine, 8, 2.

Audu , S. A., A. E. Taiwo \& A. R. Ojuolape, 2012. A study of documented phytochemistry of Vernonia amygdalina (Family Asteraceae) as the basis for pharmacologic activity of plant extract. Journal of Natural Sciences Research, 2, 7.

Ayele, C., 2006. In vivo and in vitro antifertility properties of Vernonia amygdalina Del. Masters thesis, Addis Ababa University School Of Graduate Studies, pp. 7-37. 
Effect of dietary Vernonia amygdalina Del. supplementation on some biological parameters of milt ...

Ayoola, S. O., 2009. Relationships of chemical composition, quantity of milt to fertility and hatchability of Clarias gariepinus (Burchell, 1822). African Journal of Food Agriculture Nutrition and Development, 9, 1031-1045.

Azlina, K. N., W. E. W. Khadija \& R. B. Abdullah, 2011. The effect of body weight on fresh sperm movement characteristics in African catfish (Clarias gariepinus). Journal of Animal and Veterinary Advances 10, 2215-2220.

Balogun, O. Y., 2000. Index: Nigeria. In: Senior Secondary Atlas. $2^{\text {nd }}$ edn, Longman Nig. Plc. p. 142.

Bindari,Y. R., S. Shrestha, N. Shrestha \& T. N. Gaire, 2013. Effects of nutrition on reproduction - a review. Advances in Applied Science Research, 4, 421-429.

Ciereszko, A. \& K. Dabrowski, 1995. Sperm quality and ascorbic acid concentration in rainbow trout semen are affected by dietary vitamin C: An across-season study. Biology of Reproduction, 52, 982-988.

Dada, A. A., E. O. Adeparusi \& O. V. Alale, 2010. Dietary dried Kigelia africana fruits meal as fertility enhancer in female Clarias gariepinus (BurchelI, 1822). Agriculture and Biology Journal of North America, 1, 791-795.

Dada, A. A. \& F. D. Ogunduyile, 2011. Effects of Velvet Bean (Mucuna pruriens) on sperm quality of African catfish, Clarias gariepinus (Burchell, 1822) broodstock. Journal of Fisheries and Aquatic Science, 6, 655-661.

Ebong, P. E., 2011. Ethnobotanicals: A panacea for primary health care. The $51^{\text {st }}$ inaugural lecture of the University of Calabar, Calabar, http://www.unical.edu.ng/inaug ural/0020.pdf (30 July 2013, date last accessed).

Farombi, E. O. \& O. Owoeye, 2011. Antioxidative and chemopreventive properties of Vernonia amygdalina and Garcinia biflavonoid. International Journal of Environmental Research and Public Health, 8, 2533-2555.
Fauvel, C., M. Suquet \& J. Cosson, 2010. Evaluation of fish sperm quality. Journal of Applied Ichthyology, 26, 636-643.

Francis, O. M., A. A. Akinlolu \& O. A. Kehinde, 2013. Assessment of bitter leaf (Vernonia amygdalina) as fertility enhancer in the giant African Catfish (Heterobranchus bidorsalis) broodstock. Academia Journal of Biotechnology, 1, 36-40.

Hamzah, R. U., A. A. Jigam, H. A. Makun \& E. C. Egwim, 2013. Antioxidant properties of selected african vegetables, fruits and mushrooms: a review. Mycotoxin and Food Safety in Developing Countries, ed H. A. Makun, Chapter 9. http://www. intechopen.com/books/mycotoxin-and-foodsafety-in-developingcountries/antioxidantproperties-of-selected-af rican-vegetablesfruits-and-mushrooms-a-review (29 July 2013, date last accessed).

Hassan, H. S., M. T. Odunola, M. Garba \& M. A. Usman, 2007. Effect of Vernonia amygdalina leaves on the pharmacokinetics of chlorpropamide in man. Nigerian Journal of Pharmaceutical Sciences, 6, 34-39.

Ijeh, I. I. \& C. E. C. C. Ejike, 2011. Current perspectives on the medicinal potentials of Vernonia amygdalina Del. Journal of Medicinal Plants Research, 5, 1051-1061.

Ijeh, I. I., K.K. Igwe \& C.E.C.C. Ejike, 2011. Effect of leaf aqueous extracts of Vernonia amygdalina Del on contraction of mammary gland and uterus of guinea pig dams. American Journal of Tropical Medicine \& Public Health, 1, 107-116.

Izquierdo, M. S., H. Ferna'ndez-Palacios \& A. G. J. Tacon, 2001. Effect of broodstock nutrition on reproductive performance of fish. Aquaculture, 197, 25-42.

Ligha, A. E., O. B. Kola-Ojo \& A. E. Jegede, 2013. Amelioration of histopathological effect of lead induced testicular damage by Vernonia amygdalina leaves. Research Journal of Pharmaceutical, Biological and Chemical Sciences, 4, 800-808.

Musa, S. M., C. M. Aura, C. C. Ngugi \& R. Kundu, 2012. The effect of three different feed types on growth performance and 
survival of african catfish fry (Clarias gariepinus) reared in a hatchery. ISRN Zoology, 861364.

Nalule, A. S., J. M. Mbaria \& J. W. Kimenju, 2013. In vitro anthelmintic potential of Vernonia amygdalina and Secamone africana on gastrointestinal nematodes. Agriculture and Biology Journal of North America, 4, 54-66.

Nyina-Wamwiza, L., P. S. Defreyne, L. Ngendahayo, S._Milla, S. N. M. Mandiki \& P. Kestemont, 2012. Effects of partial or total fish meal replacement by agricultural by-product diets on gonad maturation, sex steroids and vitellogenin dynamics of African catfish (Clarias gariepinus). Fish Physiology and Biochemistry, 38, 1287-1298.

Orlu, E. E. \& O. K. Ogbalu, 2011. Effect of sublethal concentrations of Lepidagathis alopecuroides (Vahl) on sperm quality, fertility and hatchability in gravid Clarias gariepinus (Burchell, 1822) broodstock. Research Journal of Environmental Toxicology, 5, 117-124.

Oteme, Z. J., R. J. Nunez, C. K. Kouassi, S. Hem \& J. F. Agnese, 1996. Testicular structure, spermatogenesis and sperm cryopreservation in the African clariid catfish Heterobranchus longifilis (Valenciennes, 1840). Aquaculture Research, 27, 805-813.

Oyedeji, K. O., A. F. Bolarinwa \& A. A. Azeez, 2013. Effect of methanolic extract of Vernonia amygdalina on reproductive parameters in male albino rats. Research Journal of Pharmacology, 7, 7-11.

Oyeyemi, M. O., O. O. Ajala, O. O. Leigh \& T. F. Adesiji, 2008. The spermiogram of male Wistar rats treated with aqueous leaf extract of Vernonia amygdalina. Folia Veterinaria, 52, 98-101.

Oyeyemi, M. O., O. K. Adeyemo, A. O. Owoyemi \& A. O.Aina, 2011. The reproductive potential of male African catfish treated with gel extract of Aloe vera plant. In: Proceedings of the $5^{\text {th }}$ Pan Commonwealth Veterinary Conference (Abstracts), Accra, Ghana. 21-25 March 2011, p. 85.
Sekoni, V., O. Gustafsson \& E. G. Mather, 1981. Influence of wet fixation, staining techniques, and storage time on bull sperm morphology. Nordisk Veterinaemedicin, 33, 161-166.

Ucheck, F. F., 2004. Vernonia amygdalina Delile. Internet Record from PROTA4U. eds Grubben, G. J. H. \& Denton, O. A. PROTA (Plant Resources of Tropical Africa/Ressources végétales de l'Afrique tropicale), Wageningen, Netherlands. http://www.prota4u.org/search.asp (18 July 2013, date last accessed).

Verma, D. K., P. Routray, C. Dash, S. Dasgupta \& J. K. Jena, 2009. Physical and biochemical characteristics of semen and ultrastructure of spermatozoa in six carp species. Turkish Journal of Fisheries and Aquatic Sciences, 9, 67-76.

Viveiros, A. T. M., E. H. Eding \& J. Komen, 2001. Effects of 17a-methyltestosterone on seminal vesicle development and semen release response in the African catfish, Clarias gariepinus. Reproduction, 122, 817-827.

Yan, L., X. Bai, Z. Fang, L. Che, S. Xu \& D. $\mathrm{Wu}, 2013$. Effect of different dietary omega-3/omega-6 fatty acid ratios on reproduction in male rats. Lipids in Health and Disease, 12, 33.

Zemjanis, R., 1970. Diagnostic and Therapeutic Techniques in Animal Reproduction, $2^{\text {nd }}$ edn, Willaims and Wilkin Co., Baltimore, USA. pp. 139-154.

Paper received 17.11.2014; accepted for publication 13.03.2015

\section{Correspondence:}

Dr. O. O. Ajala

Department of Veterinary Surgery and

Reproduction,

Faculty of Veterinary Medicine,

University of Ibadan, Nigeria.

tel: +2348023415281

e-mail: oluwatoyinajala63@yahoo.com 